\title{
Analisa Unjuk Kerja Sistem Downlink Dedicated Channel (DCH) Pada Wideband CDMA
}

\author{
Rullyanto $^{1}$, Mohamad Fathoni ${ }^{1}$ \\ ${ }^{1}$ Program Studi Teknik Elektro, Fakultas Teknik dan Sains, Universitas Nasional \\ Korespondensi: Rully_33@yahoo.co.id
}

\begin{abstract}
ABSTRAK. Sistem seluler Wideband Code Division Multiple Acces (WCDMA) saat ini berkembang sangat pesat pada tugas akhir ini dilakukan Analisa Unjuk Kerja Sistim Downlink Dedicated Channel (DCH) pada Wideband CDMA. Untuk menganalisa performa atau unjuk kerja dari sistem Downlink DCH pada Wideband CDMA dicari nilai kesalahan bit pada saat pengiriman yang biasa dikenal dengan nama Bit Error Rate pada Cyclic Redundancy Check (CRC) dan channel coding dengan input Dedicated Traffik Channel (DTCH) dan Dedicated Control Channel (DCCH) dicari nilai Bit Error Rate (BER) pada sistem Downlink Dedicated Channel (DCH) Wideband CDMA dan dicari nilai Block Error Rate (BLER) pada sistem Downlink Dedicated Channel (DCH) Wideband CDMA. Analisa ini menggunakan piranti lunak Matlab 7.0.1 untuk mengetahui jumlah kesalahan Bit Error Rate (BER) dengan jenis kanal Multipath Fading. Dari hasil simulasi dengan Input $10^{6}$ pada $7 \mathrm{~dB}$ dengan menggunakan Eb/No dari 1 hingga $7 \mathrm{~dB}$ maka didap atkan Bit Error Rate dengan nilai Bit Error Rate BER 1,8 x 10-6.
\end{abstract}

Kata kunci: Sistem downlink, CDMA, wideband, dedicated channel.

\section{PENDAHULUAN}

Dewasa ini kemajuan industri telekomunikasi telah berkembang pesat sesuai tuntutan kebutuhan pelanggan, baik untuk komunikasi suara maupun komunikasi data. Perkembangan teknologi komunikasi wireless yang berkembang dengan pesatnya memberikan banyak keuntungan bagi pengguna terminal seluler untuk menjalankan beberapa aplikasi dan layanan secara bersamaan, oleh karena itu didesainlah teknologi akses komunikasi seluler yaitu teknologi Wideband CDMA guna mendukung suatu layanan data berkecepatan tinggi.

WCDMA merupakan teknologi komunikasi wereless generasi ke-3 yang mana mampu memberikan service atau layanan sehingga para penggunanya dapat semakin mudah untuk berkomunikasi maupun mengakses, WCDMA didesain untuk dapat mengakomodasikan berbagai layanan dengan bit rate yang bervariasi sehingga memungkinkan digunakannya pemakaian spektrum yang efisien mengingat CDMA atau teknik modulasi dan metode akses jamak yang bekerja berdasarkan teknologi spread spectrum.

Pada sistem bergerak radio seluler dibutuhkan sesuatu kanal logika yang membangun hubungan antara Mobile Station (MS) dengan Base Station (BS) pada saat Uplink maupun Downlink adapun alokasi frekuensi sistem WCDMA bagi kanal Downlink berkisar antara 2110 - 2130 Mhz

\section{Jaringan Komunikasi Wireless Generasi Ke-3.}

Pengguna jaringan digital untuk keperluan komunikasi membuat kebutuhan akan jaringan digital semakin meningkat, sehingga diperlukan suatu jaringan komunikasi digital dengan kapasitas besar. Teknologi yang mendukung kebutuhan tersebut harus memenuhi persyaratan diantaranya service atau layanan yang bersifat global dan portable, untuk mendukung pita layanan lebar (multimedia) baik untuk mobile maupun WLL (Wireless Lokal Loop), interworking dengan sistem lain yang eksisting, memiliki performansi yang baik terhadap masalah propagasi dan harus memiliki efisiensi spectrum yang tinggi.

Salah satu usulan untuk teknologi 3G ini adalah Universal Mobile Telecommunication System (UMTS), yang dianggap mampu menyediakan kecepatan data (data rate) yang flaksibel, kapasitas yang lebih besar dan layanan yang lebih terintegrasi, sebelun menuju kegenerasi di atas maka telah ada generasi sebelumnya yaitu: generasi ke-1 dan generasi ke-2. Generasi ke-1 ditandai dengan teknologi analog sedangkan generasi ke-2 yang ditandai dengan teknologi 
digital dengan kecepatan rendah. Bagian ini difokuskan pada layana dan tujuan dasar dari UMTS. Sistem lain sedang dikembangkan diseluruh dunia dan banyak dari teknologi-teknologi ini yang akan dikombinasikan kedalam UMTS.

Pembangunan dan pengembangan sitem Telekomunikasi Generasi ke-3 bertujuan untuk mengatasi sejumlah permasalahan yang terdapat sistem komunikasi saat ini dengan menyediakan jaringan dengan kapasitas yang lebih besar dan terintegrasi. Saat ini ada beberapa standar untuk 3G, diantaranya UMTS, WCDMA dan IMT 2000.

\section{Tujuan Universal Mobile Telecommunicatian System.}

Tujuan utama dari Universal Mobile Telecommunicatin System (UMTS) adalah untuk menyediakan jaringan terpadu dengan kapasitas yang besar pada sistem wireless dan wireline. UMTS memungkinkan perpaduan layanan fixed dan wireless network. Akan ada tiga jenis koneksi berdasarkan kapasitasnya: mobile rate sebesar $144 \mathrm{kbps}$, portable rate sebesar 384 kbps, dan in-building rate sebesar 2 Mbps. Koneksi tersebut mampu menyediakan layanan dan fitur yang membutuhkan bandwidth kurang dari 2 Mbps, jika lebih dari 2 Mbps maka disediakan oleh jaringan tetap. UMTS mampu menyediakan alokasi bandwidth yang variable dan on-demand, serta dapat memadukan sejumlah aplikasi layanan seperti telepon tanpa kabel, telepon seluler dan mobile data networking untuk keperluan pribadi, bisnis dan perumahan.

\section{Karakteristik Propagasi dari Mobile Radio Channel.}

Pada sebuah kanal radio yang ideal, sinyal yang diterima hanya terdiri dari sebuah path sinyal langsung, yang merupakan rekonstrusi sempurna dari sinyal yang ditransmisikan. Namun dalam keadan yang sesungguhnya, sinyal dimodifikasi selama pentransmisian. Sinyal yang diterima berisi kombinasi dari pelemahan (attenuated), pemantulan (reflected), pembiasan (refracted) dan replika difraksi dari sinyal yang ditrnsmisikan. Puncaknya, kanal menambahkan nois kedalam sinyal dan menyebakan sebuah pergeseran pada frekuensi pembawa jika pemancar atau penerimanya bergerak (efek Doppler). Memahami efek tersebut sangatlah penting karena performansi dari sistem radio sangatlah bergantung pada karakteristik kanal radio..

\section{Komunikasi Spread Spectrum.}

Prinsip utama komunikasi Spread Spectrum adalah pendudukan bandwidth jauh lebih tinggi dari yang lain. Karena bandwidth yang lebih tinggi, power spectral density lebih kecil, sehingga sinyal kelihatan seperti noise dalam kanal. Penyebaran dilakukan dengan menggabungkan sinyal data dan kode (code division multiple access), di mana kode ini independen terhadap data yang dikirimkan. Beberapa keuntungannya seperti sinyal disebarkan dalam pita frequency yang lebar, Power Spectral Density-nya menjadi sangat kecil, sehingga sistem komunikasi yang lain tidak dipengaruhi oleh jenis komunikasi ini. Namun, level noise Gaussian bertambah. Dengan konsep Random Access, karena kode dalam jumlah besar dapat dihasilkan, jumlah pelanggan dalam jumlah besar diijinkan. Kemudian Jumlah maksimum pelanggan dibatasi oleh interferensi. Unutk keamanan. tanpa mengetahui kode penyebaran (spreading code), (hampir) tidak mungkin mengenali data yang terkirim. Pada Fading rejection diharapkan sistem lebih kuat terhadap distorsi, sebab bandwidth lebih lebar. Ada beberapa teknik Spread Spectrum yang dapat digunakan. Yang paling populer adalah Direct Spectrum (DS), juga yang lumayan terkenal adalah Frequency-Hopping (FH). Kombinasi keduanya (DS/FH) menawarkan banyak keuntungan dan akan menjadi basis sistem yang diajukan.

Sebuah sistem spread-spectrum harus memenuhi kriteria seperti sinyal yang dikirimkan menduduki bandwidth yang jauh lebih lebar daripada bandwidth minimum yang diperlukan untuk mengirimkan sinyal informasi, kemudian pada pengirim terjadi proses spreading yang menebarkan sinyal informasi dengan bantuan sinyal kode yang bersifat independen terhadap informasi dan pada penerima terjadi proses despreading yang melibatkan korelasi antara sinyal yang diterima dan replika sinyal kode yang dibangkitkan sendiri oleh suatu generator lokal.

Kode yang digunakan pada sistem spread spectrum memiliki sifat acak tetapi periodik sehingga disebut sinyal acak semu (pseudo random). Kode tersebut bersifat sebagai noise tapi deterministik sehingga disebut juga noise semu (pseudo noise). Pembangkit sinyal kode ini disebut Pseudo Random Generator (PRG) atau Pseudo Noise Generator (PNG). PRG inilah 
yang akan melebarkan dan sekaligus mengacak sinyal data yang akan dikirimkan. Dalam komunikasi spread spectrum semakin lebar bandwidth akan semakin tahan terhadap jamming dan akan semakin terjamin tingkat kerahasiaannya. Disamping itu akan semakin banyak kanal yang bisa dipakai. Seperti yang di terangkan oleh Shanon, salah seorang ahli statistik telekomunikasi, dalam ilmu komunikasi dinyatakan bahwa kapasitas kanal akan sebanding dengan bandwidth transmisi dan logaritmik dari S/N-nya. Jadi agar sistem komunikasi dapat bekerja dengan kapasitas kanal yang tetap pada level daya noise yang tinggi (S/N yang rendah), dapat dilakukan dengan jalan memperbesar bandwidth transmisi W. Disamping itu Shannon juga mengemukakan bahwa sebuah kanal dapat mentransmisikan informasi dengan probabilitas salah yang kecil apabila terhadap infromasi tersebut dilakukan pengkodean yang tepat dan rate infromasi yang tidak melebihi kapasitas kanal meskipun kanal tersebut memuat derau acak.

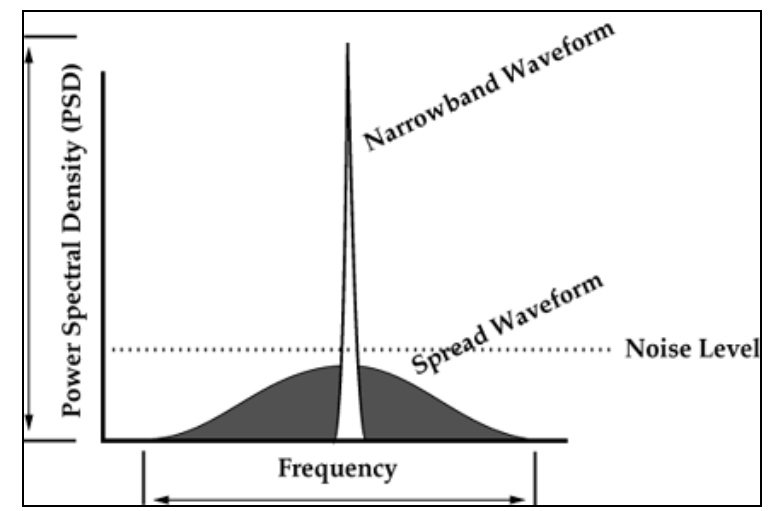

GAMBAR 1. Perbandingan gelombang spread spectrum dan gelombang narrow band.

\section{Direct Sequence.}

Direct Sequence adalah teknik Spread Spectrum paling populer. Sinyal data dikalikan dengan kode Pseudo Random Noise (PN-code).

PN-code adalah urutan chips bernilai -1 dan 1 (polar) atau 0 dan 1 (non-polar). Jumlah chip dalam satu kode disebut periode kode. PN-code adalah kode yang menyerupai noise (noise-like code) dengan properti properti tertentu.

Ada beberapa kelas binary (2-phase) PN-codes: M-sequences (base), Gold-codes dan Kasamicodes. PN-code dapat dibuat dengan satu atau lebih shiftregisters. Jika panjang dari shiftregister adalah $\mathrm{n}$, secara umum periode $\mathrm{N}$ dapat dinyatakan sbb $\mathrm{N}=2^{\mathrm{n}}-1$.

Dalam kasus paling sederhana, PN-code dikalikan dengan satu bit data (lihat gambar, dalam contoh ini $\mathrm{N}=7$ ). Bandwidth sinyal data dikalikan dengan faktor $\mathrm{N}$, faktor ini disebut sebagai processing gain.

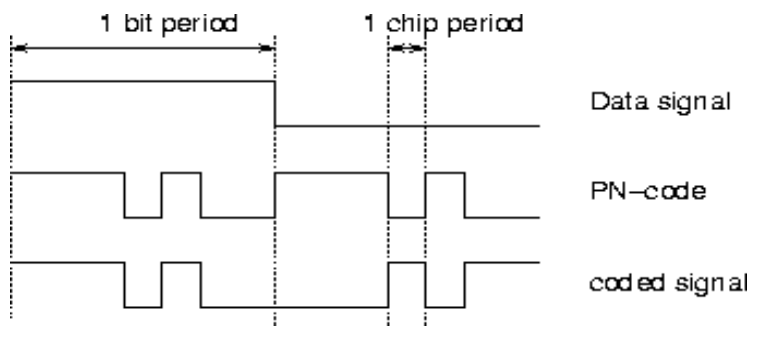

GAMBAR 2. Direct Sequence Coding.

Sinyal yang dbangkitkan dengan teknik ini nampak seperti nois yang dipancarkan ke daerah frekwensi. Lebar bidang di disajikan oleh kode suara gaduh yang pura-pura mengijinkan sinyal itu jatuh di bawah ambang noise tanpa kehilangan informasi apapun.

Berbeda halnya dengan DS (Direct Sequence), frequency hopping bukanlah sinyal yang menyebar ke seberang spektrum, tetapi suatu pancaran bandwidth dalam spektrum yang dibagi menjadi sebanyak mungkin frekwensi siaran ke data yang akan dikirimkan. 


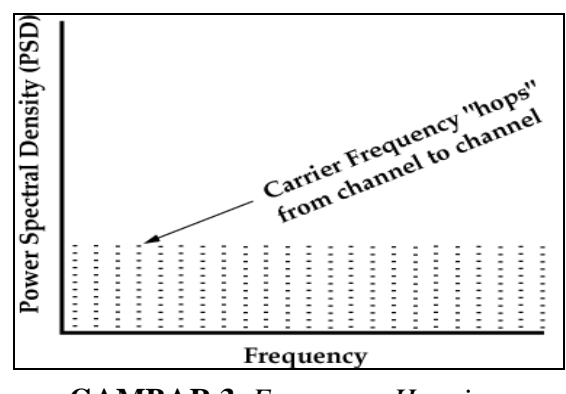

GAMBAR 3. Frequency Hopping.

Untuk Frequency Hopping, di sana ada suatu kode yang menentukan pada saat tertentu frekwensi mana yang akan dipancarkan, meloncat dari frekwensi ke frekwensi. Karenanya, satusatunya cara untuk memperoleh transmisi adalah harus mempunyai suatu kode yang identik yang mengetahui frekwensi mana yang akan melompat berikutnya.

Nilai frequency hopping sangat tinggi. Sinyal akan tinggal pada salah satu frekuensi selama kurang lebih $10 \mathrm{~ms}$, karenanya efek yang timbul sangat minim pada sinyal narrow band, seperti halnya dalam kaitan dengan sejumlah besar frekwensi yang digunakan menerjemahkan kode yang mustahil berikutnya.

\section{Sistem Wideband Code Division Multiple Acces (WCDMA)}

Sistem WCDMA adalah teknologi multiple akses dengan menggunakan modulasi DS-SS yang dapat menyediakan fasilitas pengaksesan user kejaringan PSTN (Public Switched Telephone Network) dan dapat mengirimkan servis-servis transport voice, data, facmile dan servis multimedia. Teknologi ini berbeda dengan teknik akses radio konvensial yang menggunakan teknik pembagian bandwidth frekunsi yang tersedia kekanal narrow atau kedalam time slot. Teknologi Wcdma dalam mengakses data dilakukan secara terus menerus selebar bandwidth tertentu (5-15 MHz).

Untuk membedakan masing-masing servis seperti telepon, facmile, data atau multimedia maka digunakan kode-kode tertentu yang saling berkorelasi untuk masing-masing servis dan dipenerima akan digunakan kode-kode yang sama yang saling berkorelasi.karena sistem WCDMA ini merupakan pentransmisian pita lebar.

Standar teknologi CDMA, dilihat dari spread signalnya relative lebih besar dari teknologi selular lainnya, pengurangan problem propagasi (multipath dan fading). Dikenal dua standar untuk aplikasi dengan metode akses CDMA. Standar yang dimaksud adalah IS-95 dan poprietary. Wideband CDMA mengambil konsep ini lebih lanjut dengan pengurangan multipath-fading, penawaran kapasitas dalam tiap cell dan kualitas suara yang lebih baik. Bandwidth yang luas juga membuat kemungkinan features ke depan termasuk ISDN dan bandwidth on demand. Bandwidth yang ditawarkan bersifat variatif dari mulai $1,26 \mathrm{MHz}, 5$ $\mathrm{MHz}, 10 \mathrm{MHz}$ bahkan sampai $20 \mathrm{MHz}$. Wideband CDMA dengan wireless mempunyai potensi untuk menyediakan "transparan" local loop dengan fungsi penuh seperti wireline.

Wideband CDMA sebagai WLL didesain untuk menyediakan layanan fixed dan mobile yang dikoneksikan dengan PSTN dari layanan POTS (Plain Old Telephone Service) ke featuresfeatures selanjutnya seperti ISDN dan bandwidth on demand. Service-service akan termasuk voice, high speed fax, data dan multimedia, termasuk juga video. Teknologi ini memungkinkan aplikasi ISDN ke desktop fixed wiireless dan mobile wireless.

Peluncuran layanan-layanan wideband multimedia akan menambah performansi dibanding dengan standar wireless yang ada sekarang. Wcdma sangat mendukung baik untuk komunikasi packet dan circuit switched seperti browsing Internet.

Dari awalnya, WCDMA didesain untuk layanan data kecepatan tinggi seperti internet base packet data menawarkan sampai 2 Mbps dalam lingkungan kantor dan sampai $384 \mathrm{Kbps}$ di outdoor atau lingkungan yang bergerak. Secara rinci hubungan antara besarnya carrier spacing dengan dengan bit rate maksimum yang dapat dicapai seperti yang terangkum pada tabel 1 . 
TABEL 1. Hubungan carrier spacing dan bit rate.

\begin{tabular}{|c|c|}
\hline Carrier Spacing (MHz) & Maksimum bit rate \\
\hline 1,26 & $13 \mathrm{kbps}(\sim 64 \mathrm{kbps})$ \\
\hline 5 & $64 \mathrm{kbps} \sim 384 \mathrm{kbps}$ \\
\hline 20 & $266 \mathrm{kbps} \sim 2 \mathrm{Mbps}$ \\
\hline
\end{tabular}

\section{Konfigurasi Jaringan Sistem Komunikasi WCDMA.}

Konfigurasi jaringan komunikasi WCDMAdapat dilihat pada gambar 4.

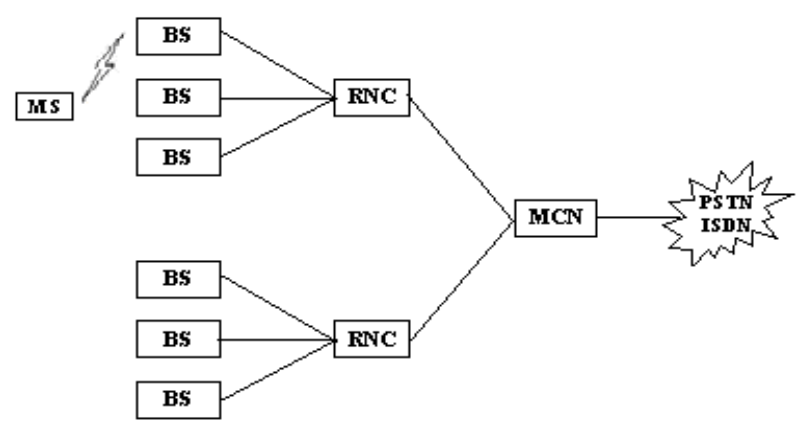

GAMBAR 4. Jaringan kesatuan fungsi mobile station (MS), base station (BS), radio network controller (RNC) dan mobile control node $(\mathrm{MCN})$.

Konsep WCDMA yang baru beroperasi dengan besar kanal radio $5 \mathrm{MHz}$ sedang dikembangkan dengan menggunakan potensi keuntungan dari CDMA. Sistem yang baru ini mempunyai beberapa keuntungan dibandingkan dengan sistem narrowband CDMA generasi ke-2 sekarang. Fitur teknologi WCDMA adalah:

- Kapasitas lebih tinggi dan penambahan coverage : sampai 8 kali lebih tinggi trafik per carrier dibandingkan dengan carrier narrowband CDMA

- Variabel dan kecepatan data yang tinggi, sampai $384 \mathrm{Kbps}$ pada wide area dan $2 \mathrm{Mbps}$ pada local area

- Service packet dan circuit switched

- Layanan multiple simultan pada tiap mobile terminal

- Mendukung untuk Hierarchical Cell Structures (HCS) pada metode handoff yang baru diantara carrier CDMA

Sedangkan pada sistem GSM tiap satu frekuensi pembawa sebesar $200 \mathrm{kHz}$ terdiri dari 8 timeslot. Tiap timeslot bisa diduduki oleh satu kanal pembicaraan. Dengan demikian dalam satu frekuensi pembawa akan mampu melayani delapan kanal pembicaraan pada waktu bersamaan. Bila digunakan untuk komunikasi data dalam satu timeslot akan mampu memberikan kecepatan data maksimum 9,6 Kbps. Tetapi biasanya dibawah nilai itu atau kira-kira $8 \mathrm{Kbps}$. Lalu bagaimana GPRS bisa memberikan kecepatan yang lebih tinggi.

Pada aplikasi penerapan sistem akses Wideband CDMA (WCDMA) pada A-bis interface jaringan eksis GSM (antara BSC dengan BTS). Penambahan sistem WCDMA pada jaringan GSM akan menambah perangkat transceiver WCDMA pada struktur A-bis interface jaringan GSM yang dapat dimanfaatkan untuk layanan data kecepatan tinggi.

Sedangkan BCF (Base Control Function) berfungsi mengatur fungsi common control antara transmitter dan receiver serta kanal fisik pada BTS. Penerapan dual mode WCDMA pada A-bis interface dilakukan dengan menambah perangkat TRX WCDMA pada BSS yang proses transmisinya diatur oleh BSC. Struktur kanal dual mode GSM/WCDMA secara garis besar terdiri atas kanal kontrol, kanal data TDMA, kanal data WCDMA. Kanal kontrol terdiri atas kanal kontrol sistem TDMA dan kanal kontrol sistem WCDMA. Penerapan teknik dual mode WCDMA pada jaringan GSM dilakukan dengan menambahkan addresing bit pada WCDMA sebagai tanda frame WCDMA, sehingga pada penerima MS atau BTS dapat mengidentifikasi frame-frame WCDMA. Adanya field address akan diidentifikasi sebagai frame WCDMA atau 
frame TDMA oleh BSC pada kanal uplink untuk pengolahan data serta mengirim ke MSC untuk keperluan routing, roaming dan lain-lain.

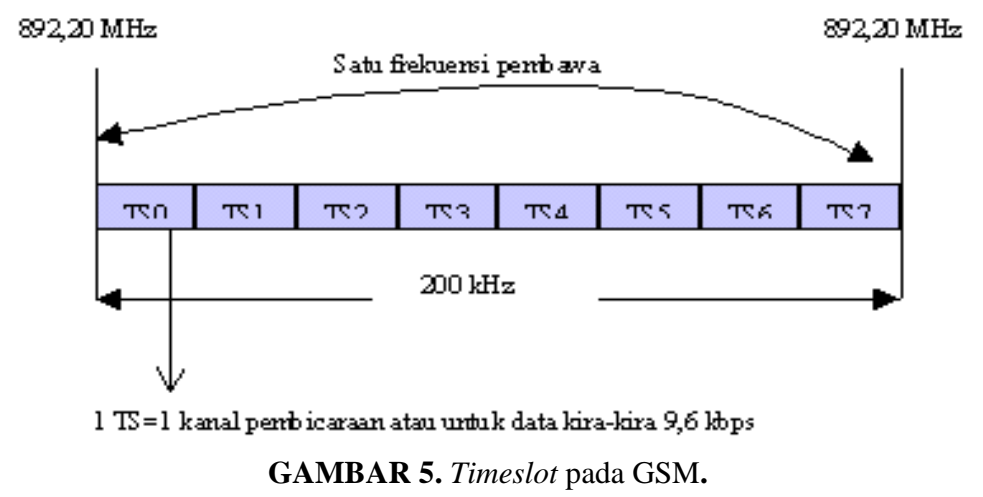

Pada sistem TDMA (GSM) adanya field address akan mengubah algoritma pemrosesan data pada radio link. Dengan adanya penambahan addressing ini maka terjadi perubahan proses channel coding pada sistem GSM. Penambahan bit addressing adalah 3 bit sehingga output dari channel coding mempunyai bit rate $(456+3) \mathrm{bit} / 20 \mathrm{~ms}=22,95 \mathrm{kbps}$. Pada sistem WCDMA terdapat field address sehingga akan mengubah algoritma channel coding dengan menambahkan field address setelah interleaving .

\section{Dedicated Channel (DCH) WCDMA.}

Transmiter WCDMA baik untuk uplink maupun downlink melakukan pengiriman trafik dan informasi kontrol secara simultan. Pengiriman trafik dan informasi kontrol yang dinotasikan sebagai Dedicated Informasi Channel (DICH).

Ketika hubungan telah terbentuk maka unit konfigurasi akan menentukan laju chip, frekuensi carrier RF, fc, yang bergantung pada layanan yang akan dilayani dan menentukan parameterparameter untuk semua pemrosesan sinyal pada kanal fisik dan mengkonfigurasi kanal fisik agar sesuai dengan layanan yang dilayani. Modulasi yang dipergunakan adalah QPSK, dimana data symbol ditransmisikan dalam bentuk in-phase (I) dan quadrator (Q) dan dikalikan dengan suatu deretan spreading yang sama dengan phasa yang berbeda [7].

\section{Downlink Dedicated Channel.}

Downlink Dedicated Channel ditransmisikan pada Downlink Dedicated Physical Channel (Downlink DPCH). Downlink DPCH menyediakan proses multiplexing waktu yang bertujuan untuk mengendalikan informasi yang berada pada layar physical dan mentransmisikan data yang ditujukan bagi para user, seperti ditujukan dalam gambar 2.13 Terminolgi dari Dedicated Physical Data Channel (DPDCH) dan Dedicated Physical Control Channel (DPCCH) yang digunakan dalam spesifikasi 3GPP untuk downlink dedicated channel.

Faktor penyebab bagi laju pengiriman data menentukan pengkanalisasian kode yang berasal dari kode-kode acak. Pengiriman laju data berbentuk variabel dapat ditetapkan dalam 2 cara yaitu :

- Disaat Transport Format Combination Indicator (TFCI) tidak ada, maka penempatan bit-bit Dedicated Physical Data Channel (DPDCH) akan teratur dalam freme. Begitupun dengan faktor penyebaran bagi laju pengiriman data juga teratur berada dalam DPCH, pengiriman data berkecepatan rendah dilakukan dengan pengiriman data yang sifatnya diskontinu atau Discontinous Transmission (DTX) dimana data tersebut dikirim atau tidak dikirim dalam selang interval waktu tertentu, hingga didapatkan laju data sebesar $1500 \mathrm{~Hz}$. Seperti halnya pada uplink dedicated channel, terdapat 15 slot per $10 \mathrm{~ms}$ freme radio; hal ini diatur oleh Blind Transport Format Detection (BTFD) yang berdasarkan pada kanal-kanal yang mempunyai posisi CRC yang berbeda-beda untuk kombinasi format pengiriman yang berbeda.

- Adanya TFCI dimungkinkan untuk jaringan dalam memilih mode operasi yang digunakan, sehingga dengan posisi pemilihan operasi yang fleksibel tersebut dapat berlangsung suatu pengiriman data yang sifatnya kontinu atau berkelanjutan. 
Kisaran faktor penyebaran kode pada DCH berkisar anatara 4 hingga 512 dimana kisaran tersebut digunakan untuk operasi handover ringan khususnya pada nilai faktor penyebaran kode tertinggi yaitu 512. adapun tujuan dari faktor penyebaran kode bertujuan untuk menyediakan informasi pada kendali daya, dan juga disaat terjadinya proses mengupload file dengan aktivitas downlink dedicated channel yang teramat minim.

Terjadinya proses modulasi menyebabkan perbedaan laju data yang dikirimkan antara uplink DCH dan downlink DCH, saat suatu data berada pada Uplink Dedicated Physical Data Channel maka data tersebut akan disisipkan dengan simbol-simbol BPSK, sementara pada downlink DPDCH data akan disisipkan dengan simbol- simbol QPSK laju dari suatu data yang diterima didownlink DPDCH dapat diakomodasikan dalam suatu kode tunggal. Laju dari suatu data downlink DCH diberikan pada tabel 2, dengan perhitungan laju bit dari simbol-simbol QPSK.

Downlink DPCH dapat menggunakan loop terbuka maupun loop tertutup dalam mengirimkan data bagi user sehingga performansi system downlink dedicated physical akan meningkat. dimana informasi akan dikodekan untuk dikirimkan dari satu antenna ke antenna yang lain. Metode ini juga diterapkan dalam spesifikasi 3GPP yang mana kode-kode data akan dikirim dalam suatu blok-blok kode. Disamping itu terdapat metode pengiriman data yang lain dimana sinyal informasi akan dikirimkan antar dua antenna berdasarkan informasi umpan balik dari terminal yang digunakan, mode umpan balik tersebut menggunakan phasa dan juga amplitudo.

\section{BLOK DIAGRAM UNJUK KERJA}

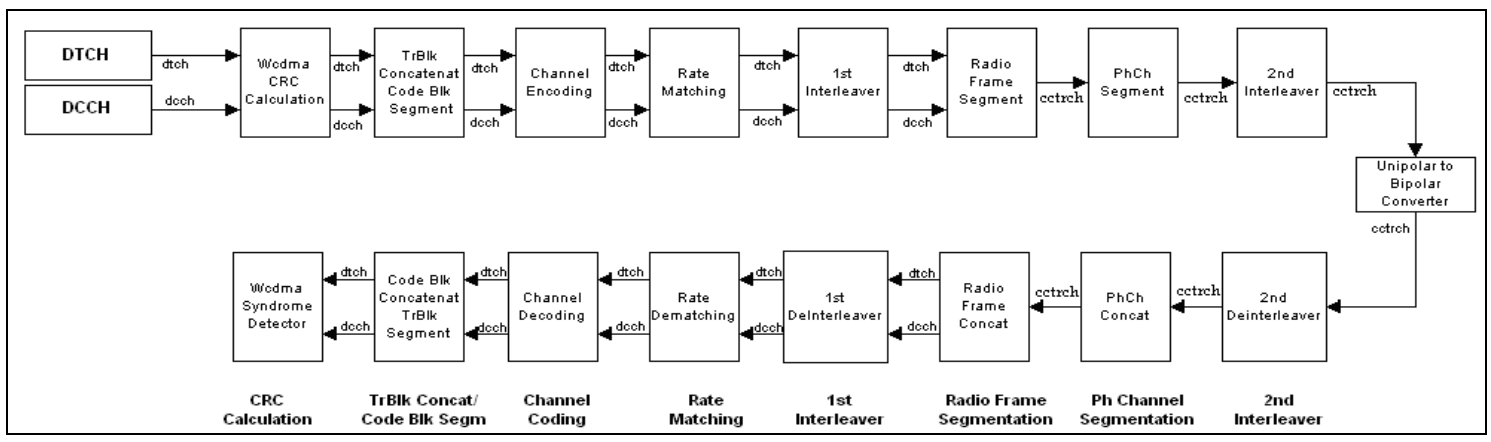

GAMBAR 6. Proses Kerja Blok Diagram.

\section{WCDMA CRC Calculation.}

Perhitungan Cyelic Redundancy Check (CRC) WCDMA digunakan untuk mengecek kesalahan kesalahan dari pengiriman blok-blok disisi penerima. Deteksi kesalahan bit disediakan oleh blok-blok transport melalui CRC. Panjang bit-bit CRC sebesar 24, 16, 12, 8 atau 0, dan lapisanlapisan lebih tinggi yang memiliki sinyal dimana panjang bit CRC harus digunakan bagi setiap kanal transport secara serial terhubung satu sama lain. Jika nilai dari bit-bit yang dikirim dalam selang waktu tertentu lebih tinggi dari ukuran maksimum blok kode, maka pembagian blok kode akan dilakukan setelah konkatenasi dari blok-blok transport.

Pada blok Rate Matching mengijinkan salah satu frame interleaving intra ataupun inter untuk ditempatkan pada kanal yang bersimbol untuk memberikan kualitas-kualitas layanan yang berbeda. Salah satu cara untuk mengubah laju sample dari sebuah sinyal, $1 /$ Tso, maka laju frame output yang tidak bernilai sama dengan laju frame input (Tfo $\neq \mathrm{Tfi}$ ), hal ini akan menyebabkan ukuran frame menjadi konstan $(\mathrm{Mo}=\mathrm{Mi})$. laju sample dari suatu sinyal dinyatakan sebagai $1 /$ Tso $=$ Mo/Tf, dimana Tso = laju sample dari sebuah sinyal (bps), Mo = ukuran frame output (bit), Tfo = waktu frame output (detik).

Interleaver yaitu proses interleaver frame radio sepanjang 20, 40 dan $80 \mathrm{~ms}$. Proses interleaver frame radio dengan waktu 20 ms akan menginterleave simbol sebanyak 384. lain halnya dengan kanal sinkronisasi yang menggunakan frame interleaver sepanjang 26.67 ms yang setara dengan interleave simbol sebanyak 128 simbol. Prose interleaver akan menulis suatu simbol-simbol kode kedalam matrix kolom bagi symbol data input lalu membaca data yang disimpan pada 
buffer output proses deinterleaver akan mengembalikan simbol-simbol interleaver pada inputinput data semula.

Pada blok Radio Frame Segmentatiion digunakan untuk memastikan bahwa data dapat dibagibagi menjadi blok-blok yang berukuran sama. Saat blok-blok tersebut dikirimkan lebih dari sebuah blok dengan panjang $10 \mathrm{~ms}$. Pada bagian Ph Channel Segmentation terjadi pembagian kanal-kanal physical dalam jumlah yang cukup banyak, dalam proses ini sinyal-sinyal binary bernoulli yang berbentuk DTCH dan DCCH tergabung menjadi sebuah sinyal digital.

Pada blok unipolar to bipolar converter ini suatu sinyal input akan diubah menjadi suatu bentuk sinyal output bipolar. Jika sinyal input tediri dari bilangan integer antara 0 dan $\mathrm{M}-1$, dimana $\mathrm{M}$ adalah parameter bilangan $M$-ary, maka sinyal output terdiri dari bilangan integer antara -(M-1) dan M-1. Bila M bernilai genap, maka output akan bernilai ganjil dan sebaliknya. Tabel 2 menunjukkan tanggapan output terhadap input nilai $\mathrm{k}$ berdasarkan nilai parameter polarisasi positif atau negatif.

.TABEL 2. Nilai output dari pengubah sinyal unipolar menjadi sinyal bipolar.

\begin{tabular}{|l|l|}
\hline \multicolumn{1}{|c|}{$\begin{array}{c}\text { Nilai parameter } \\
\text { polarisasi }\end{array}$} & $\begin{array}{c}\text { Korespon outpur terhadap } \\
\text { nilai input } \mathbf{k}\end{array}$ \\
\hline Positif & $2 \mathrm{k}-(\mathrm{M}-1)$ \\
\hline Negative & $-2 \mathrm{k}+(\mathrm{M}-1)$ \\
\hline
\end{tabular}

Bilangan parameter $M$-ary yang bernilai 4 menghasilkan nilai-nilai input yaitu (k) adalah [0; 1 ; $2 ; 3]$, sedangkan parameter polarisasinya adalah positif, maka output akan bernilai $[-3 ;-1 ; 1 ; 3]$. Sedangkan untuk parameter polarisasi negatif maka nilai outputnya menjad $[3 ; 1 ;-1 ;-3]$.

\section{HASIL UNJUK KERJA DAN ANALISA}

Hasil dari unjuk kerja ditunjukan dalam bentuk gambar dan tabel. Selanjutnya dari hasil unjuk kerja tadi dilakukan analisa performannya.

Hasil Unjuk Kerja CRC dan Channel Coding antara input dtch dan dech pada blok multiplexing ini bertujuan untuk mengetahui seberapa besar pengaruhnya untuk mengukur nilai Bit Error Rate (BER) pada beberapa keluaran sistem hasilnya diberikan pada tabel 3 .

TABEL 3. BER terhadap CRC dan Channel Coding antara input DTCH dan DCCH pada blok multiplexing.

\begin{tabular}{|l|l|l|}
\hline & \multicolumn{2}{|c|}{ Bit Error Rate (BER) } \\
\hline & \multicolumn{1}{|c|}{ DTCH } & \multicolumn{1}{c|}{ DCCH } \\
\hline Input/Output & 0 & 0 \\
\hline CRC & 0.5003 & 0.5002 \\
\hline Channel Coding & 0.4996 & 0.4978 \\
\hline
\end{tabular}

Berdasarkan dari hasil pengukuran dengan menggunakan input dtch dan dech maka menghasilkan suatu Bit Error Rate (BER), pada CRC didapat nilai BER dtch 0.5003, maupun nilai yang dihasilkan oleh dcch dengan nilai BER 0.5002. Begitu juga hasil dari pengukuran channel coding yang mana pengukuran tersebu menghasilkan Bit Error Rate (BER), dtch menghasilkan nilai BER 0.4996, begitu juga dcch dengan nilai BER 0.4978 dengan demikian BER yang dihasilkan menunjukan hasil yang baik.

Sedangkan hasil analisa unjuk kerja sistem downlink dedicated channel pada wideband CDMA di peroleh seperti pada tabel 4 , yang memperlihatkan hasil unjuk kerja untuk berbagai $\mathrm{Eb} / \mathrm{No}$ dengan interval 1 sampai $7 \mathrm{~dB}$.

Tabel 4 merupakan hasil unjuk kerja dengan jumlah data berupa bit yang dikirim dan diterima maka dihasilkan suatu Bit Error Rate yang berbeda-beda dan hasil BER yang minimum hingga 0 yang artinya tidak ada jumlah kesalahan Bit. Berdasarkan hasil tabel dari hasil unjuk kerja yang dilakukan maka grafik dapat dilihat pada gambar 7. 
Tabel 4. BER terhadap SNR untuk sistem Downlink Dedicated Channel (DCH) pada WCDMA.

\begin{tabular}{|c|l|l|l|}
\hline SNR & \multicolumn{1}{|c|}{ BLER } & \multicolumn{1}{|c|}{ BER dtch } & BER dcch \\
\hline 1 & 0,9906 & 0.3064 & 0.2763 \\
\hline 2 & 0,9383 & 0.1473 & 0.1189 \\
\hline 3 & 0,7855 & 0.03453 & 0.02984 \\
\hline 4 & 0,5845 & 0.00372 & 0.001767 \\
\hline 5 & 0.1153 & 0.000269 & 0.0001606 \\
\hline 6 & 0.009383 & 0.000001816 & 0 \\
\hline 7 & 0 & 0 & 0 \\
\hline
\end{tabular}

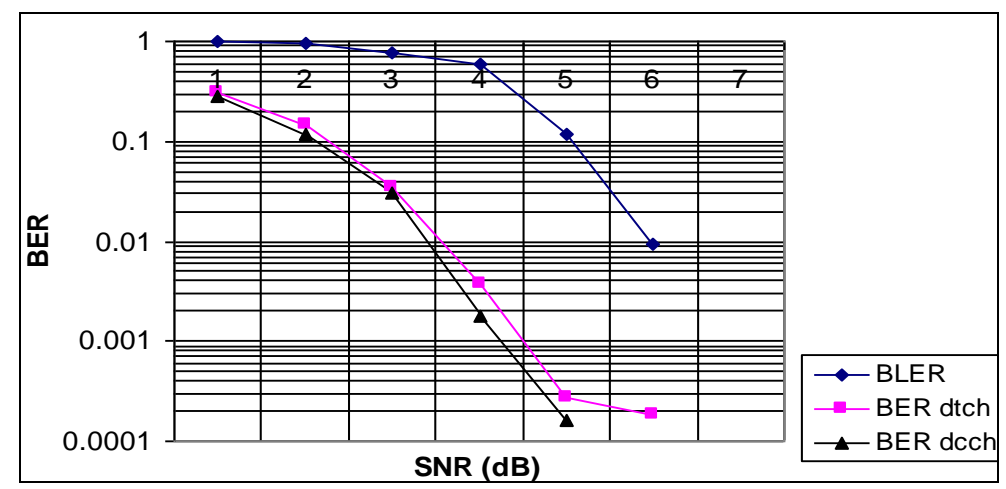

GAMBAR 7. BER terhadap SNR untuk Sistim Downlink DCH pada WCDMA dengan menggunakan kode BLER, BER dtch, BER dcch.

Berdasarkan dari hasil unjuk kerja dan gambar 7 terlihat dan dapat diamati hasil unjuk kerja bahwa semakin besar nilai Eb/No maka semakin kecil nilai BER yang terjadi, hasil unjuk kerja dapat dilihat BER dengan nilai $\mathrm{Eb} / \mathrm{No}=1 \mathrm{~dB}$ lalu di tarik garis lurus vertikal maka didapat BLER dengan hasil 0.9906, lalu lihat BER dtch dengan nilai Eb/No yang nilainya sama lalu di tarik suatu garis lurus atau vertikal maka nilai BER dtch yang dihasilkan adalah 0.3064, selanjutnya kita lihat BER dcch dengan nilai Eb/No yang sama pula maka BER dcch yang dihasilkan adalah 0.2763 , maka dengan hasil tersebut kita dapat menganalisa bahwa pada Eb/No $=1 \mathrm{~dB}$, nilai yang dihasilkan oleh BLER, BER dtch, dan BER dcch masing-masing mempunyai nilai yang berbeda, maka dengan itu BER dalam keadaan stabil.

Selanjutnya Eb/No diperbesar dengan nilai $4 \mathrm{~dB}$ pada BLER lalu di tarik garis tersebut vertikal maka BLER yang dihasilkan sebesar 0.5845, dan BER dtch dengan nilai Eb/No yang sama, nilai yang dihasilkan BER dtch sebesar 0.00372, begitu juga dengan BER dcch Eb/No yang sama pula dengan hasil nilai sebesar 0.001767, berarti Eb/No yang digunakan BER dengan nilai yang dihasilkan semakin meningkat yang artinya performa sistem semakin baik. Maka dari ketiga jenis kode tersebut dapat dilihat nilai yang dihasilkan menunjukan hasil yang cukup baik.

\section{KESIMPULAN}

Berdasarkan dari hasil Analisa Unjuk Kerja Sistem Downlink Dedicated Channel pada Wideband CDMA bahwa semakin besar nilai Eb/No maka semakin kecil nilai Bit Error Rate (BER) yang terjadi, ini berlaku bagi Dedicated Traffik Channel (DTCH) dan Dedicated Control Channel (DCCH). Downlink DPCH dapat menggunakan loop terbuka maupun loop tertutup dalam mengirimkan data bagi user sehingga performansi system downlink dedicated physical akan meningkat.

\section{DATAR PUSTAKA}

[1] 3G Frequencies http://www.umtsworld.com/technology/frequencies.htm 
[2] G Livingston, "Third Generation Wireless Standards to Shape Internet's Future", Wireless NOW, http://www.commovw.com/3rd Generation.html.

[3] M Beach,"Propagation and System Aspects", University of Bristol, Futur Communication Systems Course, April 1994

[4] T.S. Rappaport, "Wireless Communications Principles \& Practice", IEEE Press, New York, Prentice Hall, pp. 169-177,1996

[5] J.D. Gibson,’The Mobile Communications Handbook", CRC Pres, pp. 366-368,1996

[6] K. Hooli. "Adaptive Filters/LSM Algorithm "CWC. University of Oulu.

[7] Ir. Hasudungan Manurung, MT, IPM; W-CDMA sebagai Teknik Akses Sistem Komunikasi Bergerak Generasi ketiga

[8] Dahlman, E, Knutsson, J, Ovesjo, F, Persson, M. And Roobol, C, WCDMA -The Radio Interface for Future Mobile Multimedia Communications', IEEE Transaction on Vehiculer Technology, Vol. 47, No. 4, November 1998,pp. 1105-1118

[9] 3GPP Technical specification 25.212 Multiplexing and Channel Coding (FDD). 